\title{
An Evaluative Study of the English Language Practicum Program at the College of Languages and Translation at Al-Imam Muhammad Ibn Saud Islamic University
}

By

Jawharah Abdullah Haroon Al-Humaidany

A research paper submitted to the Department of English Language and Literature of the College of Languages and Translation

Dr. Mohammed I. Al-Ahaydib, Advisor

Department of English Language and Literature

College of Languages and Translation

Al-Imam Muhammad Ibn Saud Islamic University

\section{AN EVALUATIVE STUDY OF THE ENGLISH PRACTICUM PROGRAM}

\section{Abstract}

This study was conducted to evaluate the English language practicum program at the College of Languages and Translation at AlImam Muhammad Ibn Saud Islamic University in Riyadh. The sample of this study consisted of 34 participants including female student teachers and supervisors. The data were gathered by means of a thirtyone item questionnaire. The gathered data were analyzed by using SPSS software.

The study revealed that all participants were satisfied with the organization of the practicum program provided by the College although some participants confirmed that one semester of teaching practice was not enough. Moreover, almost all articipants were satisfied with the role of the university supervisor in the practicum experience. Concerning the program in general, all participants supported the idea that the program enabled students to be qualified 
EFL teachers. In addition, all participants are satisfied with the program regarding planning and implementing lessons in the class though student teachers agreed that there should be more emphasis on developing some teaching skills such as classroom management. On the other hand, a large number of participants were not satisfied with the role of the cooperating teachers and schools. Finally, both students and supervisors strongly supported the idea of having microteaching sessions in methodology courses. These sessions will provide more opportunities for the student teachers to practice their teaching skills before moving to schools. 


\section{AN EVALUATIVE STUDY OF THE ENGLISH PRACTICUM PROGRAM}

ii

\section{Chapter One}

\section{Introduction;}

Since the significance of English as a global language is increasing every day, the need for learning and teaching English has increased. According to Crystal (1997), English is taught in more than 100 countries as a foreign language. This indicates the importance of learning and teaching English.

The increasing demand for English teaching requires a highquality preparation for pre-service English language teachers in the education system.

According to Farrell (2008), teaching practice (or more popularly known as the practicum) is recognized as one of the most important aspects of teacher education. Teacher education institutions around the world, including Saudi Arabia, have tried to prepare their student teachers better for the real world of teaching. Al-Imam Muhammad Ibn Saud Islamic University in Riyadh is one of those institutions.

The practicum program at the College of Languages and Translation at Al- Imam Muhammad Ibn Saud University was established in $1406 \mathrm{AH}$. Student teachers are supposed to practice teaching English for a whole semester in their eighth level at the university in their B.A. program. There are 12 credit hours for the practicum course. Supervisors observe student teachers at least one class period per week.

The number of class periods for each student is supposed to be two class periods per day.

Supervision priority of student teachers is determined according to the following categories: faculty members, lecturers, 
teaching assistants, academic supervisors and cooperating teachers. The ultimate objective of the program is to prepare students to

experience their knowledge and skills in an authentic teaching and learning environment. It has not been determined whether the practicum program fulfills the ultimate goals of the college or not.

\subsection{Statement of the Problem}

According to the researcher's knowledge, the practicum program at the College of Languages and Translation has never been evaluated in terms of its strong and weak areas.

Although many studies have been done to investigate and evaluate practicum programs at different specializations and universities across Saudi Arabia, the results cannot be applied to practicum program of the College of Languages and Translation because these studies were carried out in a different environment.

Another reason is that the universities differ in their curricula, methodologies, and policies.

In addition, practicum time for students is the first real teaching experience they practice before they start their teaching career. Thus, it can have a very strong impression on their professional development in a positive or a negative way. Therefore, there is a well-grounded necessity to analyze and evaluate the program based on both the supervisors and the student teachers' requirements.

\subsection{Research Questions}

Since the main objective of English teaching practice is to prepare the pre-service English language teachers for the actual world of teaching, this study aims to answer the following questions:

1- What are the perceptions of the supervisors and student teachers at the College of Languages and Translation with regard to the practicum program organization?

2- What are the perceptions of the supervisors and student teachers with regard to the role of the university supervisors?

\section{2}


3- What are the perceptions of the supervisors and student teachers with regard to planning and implementing lessons?

4- What are the problems facing student teachers and supervisors in the practicum program due to the cooperating teachers and schools?

\subsection{Purpose of the Study}

This study tried to investigate the perceptions of student teachers regarding language teaching, their performance, their skills and practical obstacles they face during the practicum in order to increase their understanding of language teaching and prepare them for the career. In addition, the study tried to find whether the supervisors and students of the college were satisfied with the program. Since no study has been conducted to evaluate the program, the researcher believed that the present study would help to identify the strengths and weaknesses in the program so that the English department can make changes to enhance the strengths and reduce the weaknesses.

\subsection{Significance of the Study}

This study may have great significance because it is the first to be conducted to evaluate this program. Furthermore, the study might be of a great significance to the college administration as well as to the program planners. The results of the study would shed light on the positives and negatives of the program based on supervisors and student teachers' point of views so that changes can be made to improve the program and develop appropriate programs for future teachers.

\subsection{Definition of Terms}

Practicum: it is a "school or college course that is designed to give students supervised practical application of previously studied theory" (Pitts, 1992: 101).

Program: it " tends to evoke the image of a series of courses linked with some common goals or end products" (Pitts, 1992: 110). 
Practicum program: it is a" planned field-based clinical experience that is designed to provide counseling students with exposure to a professional environment and supervised application of previously studied theories and skills within the work setting in order to enhance the development of the students" (Bernard \& Goodyear, 2004: 25).

\subsection{Research Outline}

This research contains five chapters. The first chapter gives a brief introduction to the research scope, the statement of the problem, research questions, the purpose of the study, the significance of the study and definition of terms.

The second chapter presents the theoretical framework and the literature review. It includes literature on teacher preparation programs, importance of practicum program, factors affecting practicum program and the challenges of preparing student teachers. In addition, an overview of the English language practicum program at the College of Languages and Translation at Al-Imam Muhammad Ibn Saud Islamic University is presented. The third chapter presents the research methodology. It describes the research participants in addition to the instrument design. The fourth chapter presents the findings of the research and discussions of the results in relation to the research questions. The fifth chapter presents summary, conclusions and recommendations. It also includes suggestions for further research. 


\section{Chapter Two \\ Literature Review}

\subsection{Introduction}

One of the goals of program evaluations is to determine program effectiveness and to assess the need for program changes. There are many approaches and schools of thought to evaluate effectiveness, ranging from random experiments to in-depth case studies.

Much research has been conducted to evaluate the English language practicum program at different universities in Saudi Arabia. Al-Wabli (1982), for example, evaluated selected aspects of the secondary teacher preparation program at Umm Al-Qura University in Makkah as viewed by the program's graduates. He found out that the majority of the graduates believed that the number of observations during their student teaching experience by the supervisors was inadequate, and they were in agreement with a longer student teaching period. The graduates did not support the recommendation that supervision should be assigned to the classroom teacher instead of the college supervisor, but did support the recommendations to improve the secondary teacher preparation program. Elyas (2010) also analyzed the English language practicum programs in Saudi Arabia. He did so in order to identify the strengths and weaknesses in the program so that the department could reduce the weaknesses and increase the strengths. He also found out that both students and graduates agreed on the weakness of the program while faculty members agreed on the strength of the program.

Other studies with a similar objective were conducted by many Saudi researchers. Al-Shuaifan (2009), for instance, investigated the key components of the EFL teacher preparation program at the University of Ha'il as perceived by EFl faculty members teaching in Girls' College of Education at the University of Ha'il and EFL practitioners teaching in Girls' public schools. She found out that 
there were differences among participants with regard to the major goals of EFL teaching in public schools. But she did not demonstrate a significant difference among participants with regard to curriculum content. Her study also revealed that EFL faculty members were satisfied with the current EFL teacher preparation program while EFL practitioners were not. Moreover, Al- Hazmi (2003) studied teacher preparation programs in Saudi Arabia and the challenges facing them during their practicum experience at King Khalid University in Abha. According to Al-Hazmi (2003), the challenges facing student teachers were attributed to many factors:

insufficiency of teaching methodology before joining the program, lack of an integrated and coherent curriculum, lack of consistent and credible supervision, lack of efficient class management, using lesson planning insufficiently, and lack of communication between institutions.

Since the establishment of the College of Languages and Translation at Al- Imam Muhammad Ibn Saud University up to the present time, no research has been conducted to evaluate the English language practicum program, according to the researcher's knowledge. In order to raise the quality of the program, the program needs to be evaluated to figure out whether its objectives have been achieved, what must be changed, and what must be kept.

This chapter discusses teacher preparation programs, features of effective teacher preparation programs, practicum experience, importance of practicum program, factors affecting practicum program and challenges of preparing student teachers. Finally, the chapter ends with a review of the English language practicum program at the College of Languages and Translation (CLT) at Al-Imam Muhammad Ibn Saud Islamic University in order to provide an understanding of the evaluated program. 


\subsection{Teacher Preparation Programs}

English language teaching preparation programs have been implemented worldwide due to the international nature of the English language (William, 1994). Conferences throughout the world have discussed topics such as the nature of teacher training and different approaches to language teacher training. Rossner (1998) defined teacher preparation program as a program that aims to enable its students to be component teachers of English as a foreign language at schools or higher education.

English language teachers are able to develop themselves professionally through a variety of programs that have some similarities and differences in terms of objectives, focuses, inputs, length of times and so on. These programs can be called 'teacher training programs', 'teacher education programs', or 'teacher preparation programs' (Ur, 2000: 3).

\subsection{Features of Effective EFL Teacher Preparation Programs}

After reviewing research literature on teacher preparation programs that produce effective teachers, Brownell (2005) identified seven common features of effective teacher education programs. These features included, among other components, making connections between coursework and field experiences and having diverse experiences with supervision. Field experiences played a central role in several of the features of effective teacher preparation programs. These features are:

1- A commonality of vision between coursework and field experiences (practicum experience).

2- The ability of student teachers to connect what they learn in their courses to classroom practice.

3- Field experiences with supervision.

4- Standards maintained by faculty for student progress.

5- Faculty assistance of students in connecting what they have 
learned to practice.

6- Diversity as a part of courses and field experiences.

7- Collaboration as a strong piece of the programs.

(Brownell, 2005 as cited in Beck,2009)

Pitts (1992) also discussed that field experience is an important part of the preparation of pre-service teachers. He showed that pre-service teachers should be in teacher preparation programs that have a common curriculum connected to field experience so that pre-service teachers can learn to work with all students from a variety of diverse backgrounds.

\subsection{Practicum Program}

The practicum is considered by student teachers and teacher educators as one of the most important components of teacher preparation programs. It can be regarded as the core and climax of the teacher preparation program (Cameron \& Wilson, 1993: 155). The Council for the Accreditation of Counseling and Related Educational Programs defined the practicum as a planned learning experience that gives student teachers the opportunity to relate the theoretical classroom lessons to a supervised work experience in a learning environment (Pitts, 1997: 197).

Barry and King (2002) believed that "Teaching practice (practicum) provides the opportunity to apply the principles of teaching and learning that have been studied during course work" ( $\mathrm{p}$ : 35). They believed that learning from the practical experiences of expert teachers who observe their lessons, receiving feedback and practicing various teaching strategies during the school experience are the most important factors in student teachers' professional growth. For many, the practicum is the time for student teachers to reflect whether or not teaching is the career they want.

From this perspective, the practicum has the power to critically shape the student teacher's perception of teaching and learning. 


\subsection{Importance of Practicum Program}

In the past several decades, the importance of good teacher preparation has become even more critical because of general public dissatisfaction with public education. A large amount of research focused on the importance of teacher preparation programs in colleges and universities.

Wilson (1999), for example, mentioned that pre-service teacher preparation programs need to provide highly qualified graduates who can teach basic skills, connect their university methods courses to the classroom environment, teach to an increasingly diverse population of students in a variety of school environment, and make measurable differences in student learning. Additionally, teacher preparation programs need to graduate teachers who are confident in their teaching so that they will stay in the teaching profession past the first few years.

Practicum experience is very powerful in determining pre-service teachers' views of teaching in a real classroom compared to the micro teaching sessions at the university. It provides student teachers with an integrated progressive experience that moves them from being learners to professional teachers (Kalebic, 2005).

During practicum, student teachers have the chance to interact with students and develop their vision about the best ways of delivering proper educational content.

Student teachers become involved in the varied features of the teaching community through meetings and staffroom discussions, rules of behavior, beliefs ,ethics and attitudes of the in- service teachers (Kagan, 1992).

\subsection{Factors Affecting Practicum Program}

There are different factors affecting practicum programs. These factors have a great influence on the success of student teachers to pass the pre-service training to become real teachers. 
These factors are: university supervisor, cooperating school, school principal and cooperating teacher (Heppner, 1994).

\subsubsection{University Supervisor}

For any course that involves a practicum experience, the faculty members teaching the courses are the university supervisors. University supervisors have an important role in teacher preparation programs because of their greater experience related to the counseling practicum.

Bourke (2001) stated that the university supervisors should use variable supervision techniques such as role plays, on-site observations, individual and/or group supervision as appropriate for the needs of the student teachers and the type of fieldwork completed. The supervisors provide practicum students a written summary of program requirements at the start of the term. They also provide ongoing formative feedback and evaluation to the practicum students about their professional behavior, knowledge, and skills. The supervisor's role and responsibilities change depending on the development and requirements of the teaching-learning process and the teacher preparation methods. University supervisors seem to have more impact on practicum students than do the other factors because practicum supervisors are in many ways gatekeepers of competence, since they are in a position to discern whether or not trainees are fit to practice.

Practicum supervision should focus on teacher development rather than teacher training. Practicum supervision should concentrate on understanding the learning/teaching process rather than concentrating on learning teaching skills only.

What is taught/ learned, and how it will be applied in real situation is important in practicum teaching (Bourke, 2001).

\subsubsection{Cooperating School}

The cooperating school is the school that agrees to provide practicum students the opportunity to have their training course and 
implement theory into practice. Inside the school, there are different individuals who have a role in the practicum particularly those handling the administrative tasks. Of those individuals, field instructors (cooperating teachers) and school principle are the main individuals who have direct connections to the practicum student teachers (Ralph, 2005).

\subsubsection{School Principal}

Beside the cooperating school, Ralph (2005) discussed school principal as another factor affecting teacher practicum programs. He stated that student teachers are guided and supervised through a supervising team that consists of the cooperating teacher, university supervisor, school principal, and other school and university staff.

This team holds meetings to analyze each student teacher's performance and potential during the practicum and then recommend suitable experiences for him/her.

According to Ralph (2005), the school principal has some responsibilities towards student teachers during their practicum. $\mathrm{He} / \mathrm{she}$ is responsible for orienting the practicum candidates to the school building(s), schedule, calendar of events, instructional material center, and the expectations of the school teachers and students.

$\mathrm{He} / \mathrm{she}$ also guides the practicum candidates to learn about the processes of the school office and the principal's role. The school principal also cooperates in the supervision process of the practicum candidates through observations, team meetings, and other supervisory activities, and may also assist in the evaluation of the practicum candidates with the cooperating teacher and the university supervisor.

\subsubsection{Cooperating Teacher}

One of the factors affecting the practicum programs is the field instructor (cooperating teacher). Russell and Russell (2012) pointed out that the role of the cooperating teacher in the practicum program is to mentor student teachers and engage them in the practicum experience. This includes defining educational content in all 
areas of the field experience, and determining the nature of education theory and its relation to student teacher performance. In his article, Street (2004) summarized the role of the cooperating teacher through several points:

1. The cooperating teacher should make the practicum candidate feel a part of the school by meeting the principal, other teachers, and staff members.

2. The cooperating teacher should provide the practicum candidate with a desk, schedule, school handbooks, textbooks, and other instructional materials.

3. The cooperating teacher should conduct and participate in conferences with the practicum candidate and university supervisor.

4. The cooperating teacher should give the candidate positive help and guidance in creating practical lesson plans.

5. The cooperating teacher should encourage the practicum candidate to ask questions, observe lessons and provide the results after the lessons by offering ideas for development.

6. The cooperating teacher should hold meetings to help the practicum candidate to analyze his/her teaching behavior in terms of meaningful learning.

7. The cooperating teacher should guide the practicum candidate in selfevaluation to develop methods for improvement.

8. The cooperating teacher should model lessons in order to help student teachers transition from the planning stages at the academic level to the performance at the actual level. Street (2004)

Building on what is mentioned above, it is obvious that the role of field instructors in mentoring student teachers during the practicum forms a fundamental part of the practicum process and it also affects the level of student teachers' practice.

\section{2}


Finally, Street (2004) believed that the more the field instructor is experienced and has effective communication skills, the more student teachers feel self-confident, become more productive, and feel comfortable.

Reviewing the literature suggests that a teacher practicum program involves different factors and these factors interact with each other. People in charge should take these factors into consideration to achieve an effective teacher practicum program for EFL teachers.

\subsection{Challenges of Preparing Student Teachers}

Student teachers confront significant challenges during their practicum in the process of becoming acceptable teachers. These challenges come from both their supervising teachers and the students they are teaching (Darling-Hammond, 2000).

Some supervising teachers position their teacher candidates in the teaching role and give them more freedom to do their teaching plans and preparation. Thus, the supervisors allow the student teachers to maintain their confidence and authority in the eyes of the school students. Darling-Hammond (2000: 33) proposed that supervisors create a high level of support when they encourage, praise, and provide positive feedback to student teachers. This enhances their capacity for the experience and risk-taking. In contrast, some supervisors discouraged their student teachers by giving negative comments. Pham (2001) found that the supervisors position student teachers outside the teacher role rather than empowering them to take their place within it.

Berry (2001) stated that some supervisors provide a large number of strict directions which gives a low level of support for student teachers because "such directions don't allow the student teacher to try out ideas and experiment with methods and techniques that make sense to her/him" (p. 34). In addition, some supervisors negate the student teachers' professional identity by giving them negative comments in front of students they are teaching. This causes the student teachers to lose their authority in the class.

\section{3}


Student teachers have additional challenges coming from the students they are teaching. Kennedy (1993) stated that student teachers have an additional difficulty of dealing with the school students because they are only "temporary" teachers who would leave after the short practicum. The school students know the student teachers have limited authority. Because some of the student teachers are relatively young, the school students look at them as peers rather than real teachers. This causes the student teachers to lose their management, confidence, and authority in teaching.

In general, good preparation before class is very important for student teachers during their practicum. Good preparation can be done to overcome challenges and prevent problems during the practicum program. This preparation involves making full use of university resources, discussing classroom management strategies with the supervising teachers, and carefully studying the teaching theory provided by the university lecturers before real teaching (Wang, 2002).

\subsection{The English Language Practicum Program at the College of Languages and Translation}

In this study, the English language practicum program at the College of Languages and Translation at Al-Imam Muhammad Ibn Saud Islamic University in Riyadh is the object of evaluation. Therefore, it is necessary to report some salient features of the College of Languages and Translation as well as the English language practicum program.

In $1402 \mathrm{AH}$, the College of Languages and Translation in Riyadh was a department in the College of Arabic Language. The College of Languages and Translation was established as an independent college in $1422 \mathrm{AH}$. It is considered to be a growing college that seeks to build up the language skills of its students and provide them with cognitive and academic experiences. One of its objectives is to prepare individuals to be qualified English teachers. 
During the four academic years (eight academic levels), the students study various courses such as language skills, English literature, linguistics, translation, ELT methods, religious courses, Arabic grammar, and general educational courses.

The eighth level is assigned for the practical education which is called practicum. The ultimate objectives of the practicum program are to prepare students to experience their knowledge and skills in an authentic teaching and learning environment, and to make connections between the content of the courses that students have studied at university (EFL methodology) and its applications for classroom teaching.

English teaching methodology is taken in the sixth and seventh semesters of the third and fourth academic year. The arrangement of the methodology course intended to integrate theories and practice in order to prepare the student teachers for their teaching practicum at the fourth academic year and for their future career as English teachers in public and private schools in Saudi Arabia.

Students of the English Language Teacher Preparation program at Al-Imam Muhammad Ibn Saud Islamic University have to join public schools in Al-Riyadh City or surrounding areas to practice teaching English for a whole semester in their eighth level at the university. They are supposed to teach any of the basic educational stage classes at intermediate and secondary public schools. Student teachers choose placement of schools themselves which are generally based on their homes placement.

They are almost divided into 30 groups teaching at 30 public schools. Each group consists of 4-5 students. Students are also expected to teach 8-10 class periods per week. They are expected to teach at schools for four days and allowed to have other academic courses at the university for one day per week. To graduate, students must have earned 180 units. Out of 180, there are 12 units for the practicum course.

\section{5}


Supervision priority is determined according to the following categories:

faculty members, lecturers, teaching assistants, academic supervisors, and cooperating teachers. The university supervisor is expected to evaluate each student at one visit per week in addition to a supervision visit during the first days of the semester to give instructions. In each of the evaluation visits, the supervisor is expected to sit with the student teacher in the presence of the cooperating teacher before her class in order to discuss her lesson plan and give recommendations and instructions regarding teaching. Then, the supervisor observes the student teacher's lesson, sits in the class and takes notes about the student teacher's performance. After the lesson, the supervisor and the student teacher sit and discuss the lesson. The supervisor gives written recommendations to the student teacher to keep them in her preparation notebook, and to benefit from them in her subsequent lessons. In each visit, the supervisor fills an evaluation form of 15 items assessing the student teacher's performance (see Appendix A).

\subsection{Conclusion}

In conducting any assessment, evaluation, or analysis, it is imperative to think about how progress can be measured. Measuring indicators of progress - keeping the programs' goals and expected outcomes in mind - requires significant thought as well as a system of data collection. The methods of evaluations depend on the question and goal of the evaluation. The next chapter will discuss the methodology of this research, the process of choosing the research sample, data collection, and how data and statistics will be interpreted and analyzed. 


\section{Chapter Three \\ Research Methodology}

\subsection{Introduction}

This chapter presents the research methodology undertaken. It discusses the participants of the study, the instrument of the study as well as the validation, the content and the administration of the instrument.

\subsection{Participants}

The population of this research included two groups: female supervisors and female student teachers. A simple random statistic method was used to draw the research sample. Accordingly, 20\% of the research community was drawn randomly to represent the research sample.

Concerning the first group 'female supervisors', there are 15 female supervisors in the College of Languages and Translation. Of the female supervisors, 7 supervisors are holders of a Ph.D. degree while 2 are holders of an M.A degree and the remaining are holders of a B.A degree. The participants for this study were $4 \mathrm{Ph}$.D. holders.

Regarding the second group 'female student teachers', there are 144 female student teachers in the College of Languages and Translation. The student teachers participating in this study are in the fourth year (level 8) in the academic year 1432 - 1433 AH (20112012). Out of 144, 30 female student teachers from 6 schools participated.

\subsection{Instrument of the Study}

Data of the study were collected by means of a questionnaire. This questionnaire investigated the effectiveness of the English language teaching practicum at the College of Languages and Translation at Al-Imam Muhammad Ibn Saud Islamic University in Riyadh. Two versions of the questionnaire were used: one addresses the student teachers and the other addresses the supervisors. 


\subsection{Validation of the Questionnaire}

Two questionnaires developed by Al-Magableh (2010) and Al-Astal (2004) were used. Some items of Al-Astal's questionnaire were translated from Arabic into English. After some adaptations were made to the questionnaires, the questionnaire of this study was designed. It was given to the researcher's advisor for refinement. After final modifications, the questionnaire was validated by three professors at the College of Languages and Translation at Al-Imam Mohammad Ibn Saud Islamic University.

\subsection{Content of the Questionnaire}

The questionnaire consists of 31 items to obtain information in 5 areas: the organization of the program, the university supervisor, planning and implementing lessons, the cooperating teacher, and the cooperating school.

Part one, the organization of the program, consists of 8 items. Part two, the university supervisor, consists of 9 items. Part three, planning and implementing lessons, consists of 5 items. Part four, the cooperating teacher, consists of 4 items. Part five, the cooperating school, consists of 5 items.

Every item of the questionnaire represents a statement that the participants respond to by choosing one of four scale values: strongly agree, agree, disagree, and strongly disagree. At the beginning of the questionnaire, the purpose of the study is provided as well as instructions on how to fill out the questionnaire. In the supervisor's version of the questionnaire, general information is required including the following: name (optional) and highest academic degree.

The student teacher's version does not include any general information. The meaning of the four scale values is included: strongly agree means that the student completely agrees with the statement; agree means that the student agrees somewhat with the statement; disagree means that the student does not agree with the

\section{8}


statement; and strongly disagree means that the student completely does not agree with the statement.

\subsection{Administration of the Questionnaire}

The questionnaire was administrated to the participants of the study at the end of the first semester, in Muharram (November), of the academic year 1432-1433 AH (2011-2012).

The questionnaires of the supervisors and student teachers were personally administrated by the researcher. The student teachers filled out the questionnaire during their break time at schools. All questionnaires were collected and subsequently analyzed. The results are shown in the following chapter.

\subsection{Conclusion}

This chapter provides detailed descriptions regarding research participants, research instrument in addition to the validation, content, and administration of the research questionnaire. The following chapter will present the results and the findings of the study to the posed research questions. 


\section{Chapter Four: Data Analysis and Results}

\subsection{Introduction}

This chapter presents the analysis of data collected for this study along with the results. For the purpose of discussing the results, the responses 'strongly agree' and 'agree' have been combined to express agreement, and 'strongly disagree' and 'disagree' have been combined to express disagreement with the statements on the questionnaire.

In all tables below, $\mathrm{F}$ refers to frequency, $\%$ to percentage, $\mathrm{M}$ to mean score, and SD to standard deviation.

The questionnaire consists of 31 items to obtain information in 5 areas: program organization, the university supervisor, planning and implementing lessons, the cooperating teacher, and the cooperating school.

\subsection{Descriptive Analysis of the Data}

The following is a detailed presentation of the data collected from the research questions stated in the first chapter. For each research question, the perceptions of the two group participants 'female student teachers and female university supervisors' will be provided.

\section{The First Research Question}

What are the perceptions of the supervisors and student teachers at the College of Languages and Translation with regard to the practicum program organization?

The first part of the questionnaire, consisting of items $(1-8)$, focuses around the program organization. Responses to these items are presented in tables (4.1) and (4.2). The first item requests the student teachers to answer whether the period of the program (one semester) is not enough. The results reveal a high percentage of disagreement $(56.7 \%)$. In their response to whether the student teachers get a 
manual for the training course (item 2), 80\% of student teachers express their agreement with the statement .

Reactions to the third item show that $70 \%$ of student teachers confirm that teaching skills to be mastered are outlined for the student teachers. In response to whether the number of the students in each group is exceeding the limited number (item 4), $56.7 \%$ of students agree that this is the case.

The fifth item of the questionnaire requests the student teachers to state whether the program applies microteaching in methodology. Results show that $53.3 \%$ of student teachers express their disagreement. The data reveal that $73,4 \%$ of students confirm that English teaching methods and curricula courses at university are useful to the development of teaching practice (item 6). The seventh item requests the students to state whether the evaluation of their teaching practice is efficient. Results reveal that $96,7 \%$ of student teachers express their agreement. Finally, in reaction to whether the program qualifies the students to be proficient EFL teachers (item 8), a high percentage of students $(63,4 \%)$ express their agreement.

In responses to items ( 1 and 5), the student teachers reveal that they agree that one semester for the program is enough while they disagree that the program applies microteaching in methodology courses. On the side of the university supervisors, responses to the first item of the questionnaire reveal that $75 \%$ of the supervisors agree that one semester of the program is not enough (item 1). In reaction to whether the student teachers get a manual for the training course (item 2), a high percentage of the supervisors (75\%) express their agreement.

Statistics also reveal that all supervisors (100\%) agree with the statement suggesting that teaching skills to be mastered are outlined (item 3). In addition, reactions to the fourth item reveal that $75 \%$ of supervisors confirm that the number of student teachers in each group is exceeding the limited number (item 4). 
The data bring out that $75 \%$ of the supervisors disagree that the program applies microteaching in methodology courses (item 5).

The data expose that $75 \%$ of the supervisors agree that English teaching methods and curricula courses at university are useful to the development of teaching practice (item 6), and the evaluation of the student's teaching practice is efficient (item7). Finally, in response to whether the program qualifies the students to be proficient EFL teachers (items 8), all supervisors (100\%) agree.

The paradoxes in responses to item (5) reveal that supervisors agree that the program does not apply microteaching in methodology courses.

The Second Research Question

What are the perceptions of the supervisors and student teachers with regard to the role of the university supervisors?

The second part of the questionnaire (items $9-17$ ) deals with the role of the university supervisor in the practicum experiences.

A high percentage of student teachers $(86.7 \%)$ agree that the supervisor always draws on multi- references in assessing their performance, attendance, lesson planning, reports, and class demonstration (item9). Moreover, in response to whether the supervisor manages to establish a good rapport with the student teachers which causes her relationship with them to be not sensitive and tense (item10), 63.4\% of student teachers support that statement. Most students (76.6\%) agree that the only visit the supervisor paid to school was to assess their performance (item 11).

The results also show that $93.3 \%$ of student teachers confirm that the supervisor always suggests solutions to their problems (item12). In response to (item13), 96.7\% of student teachers agree with the statement that the supervisor always follows up lesson planning in the class.

Data reveal that $86.7 \%$ of student teachers agree that the supervisor always provides comments about the learning process (item 
14). Responses to (item 15) show that $90 \%$ of student teachers agree that the supervisor accepts their point of views. $96.7 \%$ of the student teachers agree that the supervisor's feedback to their teaching practice is efficient and clear (item 16). Finally, in reaction to item (17), 53.3\% of student teachers agree with the statement that the supervisor always holds meetings at the university to discuss what happens at the school.

Within the responses from the university supervisors, all the supervisors $(100 \%)$ support the idea that the supervisor always draws on multi- references in assessing the student's performance, attendance, lesson planning, report, and class demonstration (item 9). In addition, most supervisors (75\%) agree that the supervisor manages to establish a good rapport with the student teachers which causes her relationship with them to be not sensitive and tense (item 10). In response to whether the only visit the supervisor paid to school was to assess the student's performance (item 11), 75\% of supervisors express their disagreement.

All supervisors (100\%) agree that the supervisor always suggests solutions to the students' problems (item 12). A high percentage of supervisors $(75 \%)$ confirm that the supervisor always follows up lesson planning in the class (item 13)

All supervisors $(100 \%)$ agree that the supervisor always provides comments about the learning process (item 14), the supervisor accepts the students' point of views (item 15), and the supervisor's feedback to student's teaching practice is efficient and clear (item 16).

The data also show that all supervisors (100\%) agree that the supervisor always holds meetings at the university to discuss what happens at the school (item 17). These results are presented in table.

Responses to items (9) to (17) reveal that all participants are satisfied with the role of the university supervisor in the practicum program. On the other hand, the contradictions in the responses to item (11) show that student teachers agree that the only visit the 
supervisor paid to school was to assess their performance. In contrast, the supervisors disagree with this point.

\section{The Third Research Question:}

What are the perceptions of the supervisors and student teachers with regard to planning and implementing of lessons?

The third part of the questionnaire, consisting of items (18 22), deals with planning and implementing of lessons. Regarding the student teachers' responses, $96.6 \%$ of student teachers' confirm that they always start with prior accurate lesson planning (item 18). Statistics also show that $90 \%$ of student teachers agree that they are able to form the behavioral objectives perfectly (item 19). In reaction to whether they are able to manage their classes (item 20), 56.7\% of student teachers disagree. Moreover, the responses reveal that $90 \%$ of student teachers agree that they are able to manage discussions and asking questions (item 21). In reaction to whether it is easy for the student teachers to deal with students' different levels and backgrounds (item 22), 93.3\% of student teachers agree.

All supervisors (100\%) agree that student teachers are able manage the class (item20). Moreover, the question of whether the student teachers are able to manage discussions and asking questions (item 21$)$, all supervisors (100\%) express their agreement. The data also reveal that all supervisors (100\%) agree that it is easy for student teachers to deal with students' different levels and backgrounds (item 22).

Responses to items (18) to (22) reveal that all participants are satisfied with planning and implementing lessons.

\section{The Fourth Research Question:}

What are the problems facing student teachers and supervisors in the practicum program due to the cooperating teachers and school?

The fourth part of the questionnaire, consisting of items (23 $26)$, focuses around the cooperating teacher. Responses to these items are presented in tables (4.7) and (4.8). 
A high percentage of student teachers $(80 \%)$ agree that the cooperating teacher needs training on how to deal with the training program (item 23). In their response to whether the cooperating teacher wants student teachers to teach subjects she taught to her students before (item 24), 63.3\% of student teachers express their disagreement with the statement. $66.7 \%$ of student teachers agree that the cooperating teacher helps them to attend the classes of their peers regularly (item 25). Finally, in reaction to item (26), 66.7\% of student teachers disagree with the statement that the cooperating teacher provides enough support to the student teacher.

In reaction to whether the cooperating teacher helps the student teachers to attend the classes of their peers regularly (item 25), $75 \%$ of supervisors disagree.

Finally, in reaction to item (26), 75\% of supervisors disagree with the statement that the cooperating teacher provides enough support to the student teache.

\section{The fifth part of the questionnaire (items 27 - 31) deals with the cooperating school.}

A high percentage of student teachers $(83.3 \%)$ agree that the cooperating school does not provide necessary teaching aids (item 27). $66.7 \%$ of student teachers agree that the cooperating school does not provide a meeting room for the supervisor and the student teachers (item 28).

Responses to item (29) bring out that $50 \%$ of student teachers agree that students at school do not look at them as teachers and follow their instructions. The data also show that $60 \%$ of student teachers agree that classes are very crowded so they are not able to implement what they have learnt at the university (item 30).

Finally, in reactions to whether school books and teachers' handbooks are not always available (item 31 ), 60\% of student teachers express their agreement. 
On the side of the supervisors, responses to item (27) show that $75 \%$ of the supervisors disagree with the statement that the cooperating school does not provide necessary teaching aids. In reaction to whether the cooperating school does not provide a meeting room for the supervisor and student teachers (item 28 ), $75 \%$ of the supervisors express their disagreement.

Statistics also that $50 \%$ of the supervisors agree with the statement suggesting that the students at school do not look at the student teachers as real teachers and follow their instructions (item 29). All supervisors $(100 \%)$ agree that classes are very crowded so student teachers are not able to implement what they have learnt at the university (item 30). In addition, reactions to item (31) reveal that $75 \%$ of supervisors confirm that the school books and teachers' handbooks are not always available.

Responses to items (27) to (31) reveal that all participants are not satisfied with the role of the cooperating school. However, supervisors agree that the cooperating school provides necessary teaching aids (item 27), as well as a meeting room for the supervisor and student teachers (item 28). 


\section{Chapter Five}

\section{Summary, Conclusion and Recommendations}

\subsection{Summary and Conclusion}

Although much research has been conducted to evaluate the English language practicum program in many different universities in Saudi Arabia, the English language practicum program at the College of Languages and Translation at Al-Imam Muhammad Ibn Saud Islamic University in Riyadh has never been evaluated. The primary purpose of this research was to evaluate this program based on the student teachers' and supervisors' point of views.

The study covered different areas and topics that the researcher believed to be relevant to the study such as teacher preparation programs, practicum experience, factors affecting practicum experience, and the challenges facing student teachers.

The data for this research were collected by means of a 31item questionnaire. There were two versions of the questionnaire: one for the student teachers and the other for the university supervisors. The questionnaires were distributed to a random sample of level-seven and level-eight female students, and female supervisors.

All collected data were analyzed by using SPSS software (Statistical Package for ocial Sciences). A comprehensive description of the analyzed data was presented by using statistical measures to each item of the questionnaire. The main findings of the research can be summarized in the following points:

1- In the light of the program organization:

A. The organization of the practicum program provided by the college is adequate though all supervisors confirm that one semester of teaching practice is not enough. On the other hand, a large number of student teachers agree that it is enough

B. All participants agree that the number of student teachers in each group is exceeding the limited number. 
C. All participants confirm that the program does not apply microteaching in methodology courses.

D. A large number of the participants agree that the program qualifies student teachers to be proficient EFL teachers.

2- Concerning the role of the university supervisor:

a. All participants agree that the program is successful with regard to the role of university supervisors with the exception of student teachers who are not satisfied with the number of supervisors' visits to schools. A large number of student teachers agree that the only visit the supervisor paid to school was to assess their performance.

b. The university supervisors always hold meetings at the university to discuss what happens at the school.

c. All participants agree that the university supervisors always suggest solutions to student teachers' problems, provide comments about learning process, accept the students' point of views, and provide an efficient and clear feedback.

\section{3- Concerning planning and implementing lessons :}

A. All participants are satisfied with the program regarding planning and implementing lessons in the class.

B. All supervisors agree that the program succeeds in teaching classroom management to student teachers. Though, a large number of student teachers disagree with this point.

C. All participants agree that student teachers are able to start with prior accurate lessons planning, form the behavioral objectives perfectly, manage discussions, and ask questions.

D. All participants find it easy for student teachers to deal with school students' different levels and backgrounds.

\section{4- Concerning the cooperating teacher:}

A. a- All participants confirm that the cooperating teachers need training on how to deal with the training program. 
B. b- A large number of supervisors agree that the cooperating teacher wants student teachers to teach subjects she taught to her students before. On the other hand, student teachers disagree with this point.

C. c- Although student teachers agree that the cooperating teacher helps them to

D. attend classes of their peers regularly, student teachers do not.

E. d- All participants confirm that the cooperating teacher does not provide

F. enough support to the student teachers during their practicum program.

5- Concerning the cooperating school:

A. a- A large number of student teachers agree that the cooperating school does not provide necessary teaching aids.

B. b- Although supervisors agree that the cooperating school provides a meeting room for the supervisor and the student teachers, student teachers do not.

C. c- A large number of the participants confirm that students at school do not look at student teachers as real teachers.

D. d- Classes at schools are very crowded, so student teachers are not able to implement what they have learnt at the university.

E. e- All participants confirm that the school books and teachers' handbooks are not always available.

\subsection{Recommendations}

In the light of these conclusions, the researcher suggests the following recommendations to improve the English language practicum program at the College of Languages and Translation at AlImam Muhammad Ibn Saud Islamic University:

1- The practicum period (one semester) should be increased because student teachers need more than one semester to transfer what they have learnt at the university into their classrooms. 
2- The program should maintain the recommended number of student teachers in each group. This would permit additional observations with feedback for each student teacher.

3- The program should apply microteaching in methodology courses. This microteaching will provide more opportunities for the student teachers to practice their teaching skills before moving to schools.

4- Since the college aims to graduate competent teachers, the number of applied linguistics and TEFL courses should be increased.

5- Supervisors should increase their visits to the schools so that negotiation, interaction and discussion can take place between student teachers and their supervisor.

6- There should be more emphasis on developing some teaching skills such as classroom management.

7- There should be more emphasis on modern teaching methods in student teaching. This will help student teachers to be well-prepared to face teaching challenges.

8- As cooperating teachers do not help student teachers to develop their personal skills at a high level, the university should provide more sessions to improve students' confidence, academic qualification, and classroom management before the practicum experience.

9- There must be intensive sessions on preparing teaching aids before the school experience. This will enable student teachers to prepare teaching aids more skillfully. Also, they will be able to collect activities and worksheets they need during their practicum experience.

10- There must be orientation for the school students to have the right impression about the trainees and purposes of training.

11- Qualified cooperating teachers should be chosen according to a group of training-related professional criteria. A scale can be developed for this purpose including qualification, experiences in supervision, teaching and training, willingness of participation in training, familiarity with the training program, behavior at school and relation 
to colleagues.

12- Cooperating schools should be carefully chosen so that student teachers will be able to participate in classrooms and schools that include a rich variety of programs and students.

13- It is important for the college to choose schools which are able to provide necessary teaching aids, meeting rooms for the supervisor and student teachers, classes with appropriate number of students, school books and teachers' handbooks.

14- It is better to assign supervision to the college supervisor instead of the classroom teacher by the Curriculum and Methods of Teaching Department.

15- There should be one supervisor who would help to connect university coursework to the practicum experience by establishing and maintaining connections with the university faculty, cooperating teachers, and principals at the cooperating schools.

\subsection{Suggestions for Further Research}

This study conducted to evaluate the English language practicum program at the College of Languages and Translation. Future studies will be on the following topics:

1- A study examining the important issues to be emphasized in EFL teacher preparation programs as perceived by in-service and preservice teachers.

2- A comparative study based on cooperating teachers and student teachers' erspectives.

3- A comparative study of student teachers' perceptions between the English practicum program at the College of Language and Translation at Al-Imam Muhammad Ibn Saud Islamic University and another university in Saudi Arabia.

4- A more detailed study that concentrates on specific aspects of the English practicum program. For example, a study of the perceptions of male and female student teachers. 


\section{References}

Al-Hazmi, S.(2003). EFL teacher preparation programs in Saudi Arabia: trends and challenges. TESOL Quarterly 37 (2), 341 - 344. Retrieved 5 October, 2012 from http://onlinelibrary.wiley.com/doi/10.2307/3588509/abstra $\underline{\mathrm{ct}}$

Al-Magableh, A. M. (2010). An evaluation of English practicum at Yarmouk University from cooperative teachers and student-teachers' perspective 4(4), 19-56.Retrieved 28 October, 2012 from http://www.yazikopen.org.uk/yazikopen/ node/1707

Al-Shuaifan, A. S. (2009). Key elements of the ESL/EFL teacher preparation program at the University of $\mathrm{Ha}$ 'il, Saudi Arabia: EFL practitioners and faculty perceptions. Retrieved from ProQuest Digital Dissertations. (AAT 3377474)

Al- Wabli, S. M. (1982). An evaluation of selected aspects of the secondary teacher

preparation program at Umm Al-Qura University, Makkah, Saudi Arabia,

based on a follow-up of 1978-79 graduates. Retrieved from ProQuest Digital

Dissertations.(8216516)

Barry, K. \& King, L. (2002). Beginning teaching and beyond (3rd ed.). Tuggerah, NSW: Social Science Press.

Beck, V. L (2009). Impact of supervised practicum performance and feedback on pre-service teacher development with retrospective perceptions of practicing teachers. Retrieved from ProQuest Digital Dissertations.(3362216) Bernard, J.N.\& Goodyear, R.K.(2004). Fundamentals of 
clinical supervision. ( $3^{\text {rd }}$ ed.). Boston, MA: Allyn and Bacon.

Berry, B. (2001). No shortcuts to preparing good teachers. Educational Leadership, 58(5), 32-36.

Bourke, J. M. (2001). The role of the TP TESL supervisor. Journal of Education for Teaching,1 (27), 63-74.

Brownell, M. (2005). Critical features of special education teacher preparation: A comparison with general teacher education. The Journal of Special Education, 38(4), 242-252.

Cameron, R. \& Wilson, S. (1993). The practicum: Student teacher perception of teacher supervision styles. South Pacific Journal of Teacher Education, 21 (2), 15516.

Crystal, D. (1997). English as a global language. Cambridge: Cambridge University Press.

Darling-Hammond, L. (2000). Teacher quality and student achievement: A review of state policy evidence. Education Policy Analysis Archives.8 (1), 1-49.

Elyas, T. (2010). Saudi Arabian educational history: Impacts on English language teaching. Retrieved from ProQuest Digital Dissertations.

Farrell, T. (2008). 'Here's the book, go teach the class' ELT practicum support. RELC, 39(2), 226-241.

Freeman, D. (1990). Intervening in practice teaching. In Jack Richards \& David Nunan (Ed.), Second Language Teacher Education. (p.103-117). NY: Cambridge University Press.

Heppner, M. J. (1994). An Empirical Investigation of the Effects of a Teaching Practicum on Prospective Faculty. Journal of Counseling \& Development, 72, 500507. 
Kagan, D. M. (1992). Professional Growth among Pre-service and Beginning Teachers. Review of Educational Research, 62(2), 129-169.

Kalebic, S. C. (2005). Towards the development of standards in foreign language teacher preparation. Paper presented at 30th ATEEA (Association for Teacher Education in Europe). Annual Conference Amsterdam, Netherlands. Retrieved October 14, 2012 from www.atee2005.nl/download/papers/05_ab.pdf

Kennedy, J. (1993). Meeting the needs of teacher training practice. ELT Journal, 47(2), 157-165.

Keogh, J., Dole, S. \& Hudson, E. (2005). Supervisor or mentor? Questioning the quality of preservice teacher practicum experiences. KEO06101. Retrieved October $\quad 10 \quad 2012 \quad$ from http://www.aare.edu.au/06pap/keo06101.pdf

Pham, H. H. (2001). Teacher development: A real need for English departments in Vietnam. English Teaching Forum, 39(4). Retrieved 22 September, 2012 from http://exchanges.state.gov/forum/vols/vol39/no4/p30.htm

Pitts, J. H. (1992). Organizing a practicum and internship program in counselor education. Counselor Educational Supervision, 31 (4), 196-207.

Pettis, J. (1997). Developing our professional competence; Some reflections. TESL Canada Journal, 14(2). Retrieved October 15, 2012 from http://www. teslcanadajournal.ca/index.php/tesl/index

Ralph G. E. (2005). Factors Affecting Teacher-Candidates' Practicum Evaluations. Journal of teaching and learning,3 ( 2 ), 29-46. 
Rossner, R. (1988). Selecting teacher educators-establishing criteria. In T. Duff (Ed), Explorations in teacher training: Problems and issues. Essex: Longman.

Russell, M. I., \& Russell, J. A. (2011). Mentoring relationships: Cooperating teachers' perspectives on mentoring student interns. The Professional Educator,35(2) Retrieved September 20, 2012 from http://www.auburn.edu/ Academic/societies/professional_educator/articles/Russel_ final.pdf

Street, C. (2004). Examining learning to teach through a social lens: How mentors guide newcomers into a professional community of learners. Teacher Education Quarterly, 31(2), 7-14.

Ur, P. (2000). A course in language teaching: Practice and theory. United Kingdom: Cambridge University Press.

Wang, J. (2002). Mentored learning to teach according to standardsbased reform: A critical review. Review of Educational Research, 72(3), 481.

Williams, M. (1994). Teacher training for English language teachers. In G. R. Harvard \& P. Hodkinson (Eds.), Action and reflection in teacher education (pp. 213-227). Norwood, NJ: Ablex.

Wilson, S. (1999). Initial teacher education in Canada.The practicum. Retrieved October 4, 2012 from http:/www.seeeducoop.net/education_in/pdf/initial teacher_educ_canada-oth-enlt03.pdf

Yan, C. (2010). Transforming the existing model of teaching practicum: a study of Chinese EFL student teachers' perceptions. ELT Journal,36(1). Retrieved October 4, 2012 from http://www.msvu.ca/en/home/library/default.aspx 


\section{AN EVALUATIVE STUDY OF THE ENGLISH PRACTICUM PROGRAM}
Appendix A
Observation
Checklist

Name of student teacher:

Date:

\begin{tabular}{|l|l|l|l|l|l||}
\hline \multicolumn{1}{|c|}{ Criteria } & Excellent & Average & Weak & Marks & $\begin{array}{c}\text { Deserved } \\
\text { mark }\end{array}$ \\
\hline \hline 1-Lesson Planning. & & & & 10 & \\
\hline $\begin{array}{l}\text { 2-Classroom Interaction/ } \\
\text { tone of } \\
\text { voice. }\end{array}$ & & & & & \\
\hline 3-Instruction Giving. & & & & 5 & \\
\hline $\begin{array}{l}\text { 4-Handling of Audio Visual } \\
\text { aids. }\end{array}$ & & & & 5 & \\
\hline $\begin{array}{l}\text { 5-Use of varied activities. } \\
\text { 6-Use of varied teaching } \\
\text { techniques. }\end{array}$ & & & & 5 & \\
\hline $\begin{array}{l}\text { 7-Use of meaningful } \\
\text { context/situation. }\end{array}$ & & & & 10 & \\
\hline $\begin{array}{l}\text { 8-Teacher's language } \\
\text { proficiency. }\end{array}$ & & & & 10 & \\
\hline $\begin{array}{l}\text { 9-Timing \& balance of } \\
\text { activities. }\end{array}$ & & & & 5 & \\
\hline $\begin{array}{l}\text { 10-General classroom } \\
\text { management. }\end{array}$ & & & & 10 & \\
\hline $\begin{array}{l}\text { 11-Rapport \& student } \\
\text { Engagement. }\end{array}$ & & & & & \\
\hline $\begin{array}{l}\text { 12-Teacher's self- } \\
\text { confidence. }\end{array}$ & & & & & \\
\hline
\end{tabular}




\begin{tabular}{|l|l|l|l|l|l||}
\hline \multicolumn{1}{|c|}{ Criteria } & Excellent & Average & Weak & Marks & $\begin{array}{c}\text { Deserved } \\
\text { mark }\end{array}$ \\
\hline \hline $\begin{array}{l}\text { 13-Teacher's appearance } \\
\text { and behavior. }\end{array}$ & & & & & \\
\hline $\begin{array}{l}\text { 14-Teacher's portfolio. } \\
\text { 15-Host school director's } \\
\text { mark. }\end{array}$ & & & & 10 & \\
\hline Total & & & & 10 & \\
\hline
\end{tabular}

Supervisor's name:

Supervisor's signature: 


\title{
AN EVALUATIVE STUDY OF THE ENGLISH PRACTICUM PROGRAM
}

\author{
Appendix B \\ Questionnaire for Students \\ Dear student teacher,
}

This questionnaire investigates the effectiveness of the practicum program at the College of Languages and Translation at Al-Imam Muhammad Ibn Saud Islamic University. Please respond to each item by marking (¥) in the appropriate column that expresses your opinion. The options are as follow:

Agree: means that you agree somewhat with the statement.

Strongly Agree: means that you completely agree with the statement.

Disagree: means that you do not agree with the statement.

Strongly Disagree: means that you completely do not agree with the statement. 
a. In relation to the program organization :

\begin{tabular}{|c|c|c|c|c|}
\hline & 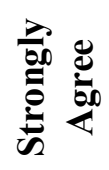 & 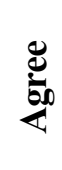 & 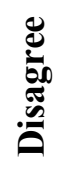 & 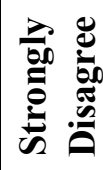 \\
\hline 1- One semester of teaching practice is not enough. & & & & \\
\hline 2-I get a manual for the training course. & & & & \\
\hline $\begin{array}{l}\text { 3-Teaching skills to be mastered are outlined for } \\
\text { trainees. }\end{array}$ & & & & \\
\hline $\begin{array}{l}\text { 4- The number of student teachers in each group is } \\
\text { exceeding the limited number. }\end{array}$ & & & & \\
\hline $\begin{array}{l}\text { 5-The program applies microteaching in } \\
\text { methodology courses. }\end{array}$ & & & & \\
\hline $\begin{array}{l}\text { 6- English teaching methods and curricula courses at } \\
\text { university are useful to the development of teaching } \\
\text { practice. }\end{array}$ & & & & \\
\hline 7- The evaluation of my teaching practice is efficient. & & & & \\
\hline $\begin{array}{l}\text { 8- The program qualifies me to be a proficient EFL } \\
\text { teacher. }\end{array}$ & & & & \\
\hline
\end{tabular}


AN EVALUATIVE STUDY OF THE ENGLISH

PRACTICUM PROGRAM

b. In relation to the role of the university supervisor:

\begin{tabular}{|l|l|l|l|l||}
\hline & & & & \\
\hline \hline $\begin{array}{l}\text { 9-The supervisor always draws on multi- } \\
\text { references in assessing my performance, } \\
\text { attendance, lesson planning, reports, and class } \\
\text { demonstration. }\end{array}$ & & & & \\
\hline $\begin{array}{l}\text { 10-The supervisor manages to establish a good } \\
\text { rapport with me which causes her relationship with } \\
\text { me to be not sensitive and tense }\end{array}$ & & & & \\
\hline $\begin{array}{l}\text { 11-The only visit the supervisor paid to school was } \\
\text { to assess my performance. }\end{array}$ & & & & \\
\hline $\begin{array}{l}\text { 12-The supervisor always suggests solutions to my } \\
\text { problems. }\end{array}$ & & & & \\
\hline $\begin{array}{l}\text { 13-The supervisor always follows up lesson } \\
\text { planning in the class. }\end{array}$ & & & & \\
\hline $\begin{array}{l}\text { 14-The supervisor always provides comments } \\
\text { about the learning process. }\end{array}$ & & & & \\
\hline 15-The supervisor accepts my point of views. & & & & \\
\hline $\begin{array}{l}\text { 16-The supervisor's feedback to my teaching } \\
\text { practice is efficient and clear. }\end{array}$ & & & & \\
\hline $\begin{array}{l}\text { 17-The supervisor always holds meetings at the } \\
\text { university to discuss what happens at the school. }\end{array}$ & & & & \\
\hline
\end{tabular}


c. In relation to planning and implementing lessons:

\begin{tabular}{|l|l|l|l|l||}
\hline & & & & \\
\hline
\end{tabular}

\section{AN EVALUATIVE STUDY OF THE ENGLISH PRACTICUM PROGRAM}

\section{d. In relation to the cooperating teacher :}

\begin{tabular}{|l|l|l|l|l||}
\hline & & & & \\
\hline \hline $\begin{array}{l}\text { 23- The cooperating teacher needs training on } \\
\text { how to deal with the training program. }\end{array}$ & & & & \\
\hline $\begin{array}{l}\text { 24- The cooperating teacher wants me to teach } \\
\text { subjects she taught to her students before. }\end{array}$ & & & \\
\hline $\begin{array}{l}\text { 25-The cooperating teacher helps me to attend the } \\
\text { classes of my peers regularly. }\end{array}$ & & & & \\
\hline $\begin{array}{l}\text { 26- The cooperating teacher provides enough } \\
\text { support to the student teachers. }\end{array}$ & & & & \\
\hline
\end{tabular}


e. In relation to the cooperating school :

\begin{tabular}{|c|c|c|c|c|}
\hline & 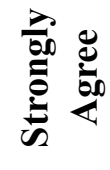 & 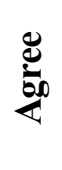 & 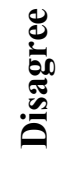 & 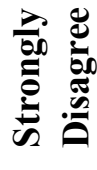 \\
\hline $\begin{array}{l}\text { 27-The cooperating school does not provide nec } \\
\text { teaching aids }\end{array}$ & & & & \\
\hline $\begin{array}{l}\text { 28- The cooperating school does not provide } \\
\text { a meeting room for the supervisor and the stud } \\
\text { teachers. }\end{array}$ & & & & \\
\hline $\begin{array}{l}\text { 29- Students at school do not look at me as a } \\
\text { teacher and follow my instructions }\end{array}$ & & & & \\
\hline $\begin{array}{l}\text { 30-classes are very crowded so I am not able to } \\
\text { implement what I have learnt at the university. }\end{array}$ & & & & \\
\hline $\begin{array}{l}31 \text {-school books and teacher's handbook are not } \\
\text { always available. }\end{array}$ & & & & \\
\hline
\end{tabular}




\title{
AN EVALUATIVE STUDY OF THE ENGLISH PRACTICUM PROGRAM
}

\author{
Appendix C \\ Questionnaire for \\ Supervisors
}

Dear supervisor,

This questionnaire investigates the effectiveness of the practicum program at the College of Languages and Translation at Al-Imam Muhammad Ibn Saud

Islamic University. Please respond to each item by marking (¥) in the

appropriate column that expresses your opinion. The options are as follow:

Agree: means that you agree somewhat with the statement.

Strongly Agree: means that you completely agree with the statement.

Disagree: means that you do not agree with the statement.

Strongly Disagree: means that you completely do not agree with the statement.

General Information:

Name (optional):

Highest academic degree: 


\section{a. In relation to the program organization :}

\begin{tabular}{|l|l|l|l|l|}
\hline & & & & \\
\hline \hline 1- One semester of teaching practice is not enough. & & & & \\
\hline $\begin{array}{l}\text { 2-The student teacher gets a manual for the training } \\
\text { course. }\end{array}$ & & & & \\
\hline $\begin{array}{l}\text { 3-Teaching skills to be mastered are outlined for } \\
\text { trainees. }\end{array}$ & & & & \\
\hline $\begin{array}{l}\text { 4- The number of student teachers in each group is } \\
\text { exceeding the limited number. }\end{array}$ & & & & \\
\hline $\begin{array}{l}\text { 5-The program applies microteaching in } \\
\text { methodology courses. }\end{array}$ & & & & \\
\hline $\begin{array}{l}\text { 6- English teaching methods and curricula courses at } \\
\text { university are useful to the development of teaching } \\
\text { practice. }\end{array}$ & & & & \\
\hline $\begin{array}{l}\text { 7- The evaluation of the student's teaching practice is } \\
\text { efficient. }\end{array}$ & & & & \\
\hline $\begin{array}{l}\text { 8- The program qualifies the student to be } \\
\text { a proficient EFL teacher. }\end{array}$ & & & & \\
\hline
\end{tabular}




\section{AN EVALUATIVE STUDY OF THE ENGLISH PRACTICUM PROGRAM}

\section{b. In relation to the role of the university supervisor :}

\begin{tabular}{|c|c|c|c|c|}
\hline & $\frac{\lambda}{\infty}$ & 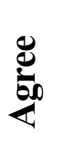 & 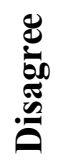 & 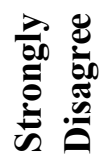 \\
\hline \multicolumn{5}{|c|}{$\begin{array}{l}\text { 9- I always draw on multi-references in assessing the } \\
\text { student's performance, attendance, lesson } \\
\text { planning, reports, and class demonstration }\end{array}$} \\
\hline \multicolumn{5}{|l|}{$\begin{array}{l}10 \text { - I manage to establish a good rapport with the } \\
\text { student teachers which causes my relationship } \\
\text { with them to be not sensitive and tense. }\end{array}$} \\
\hline \multicolumn{5}{|l|}{$\begin{array}{l}\text { 11-The only visit I paid to school was to assess the } \\
\text { student's performance. }\end{array}$} \\
\hline \multicolumn{5}{|l|}{$\begin{array}{l}\text { 12- I always suggest solutions to the students' } \\
\text { problems. }\end{array}$} \\
\hline \multicolumn{5}{|l|}{$\begin{array}{l}\text { 13- I always follow up lesson planning in the } \\
\text { class. }\end{array}$} \\
\hline \multicolumn{5}{|l|}{$\begin{array}{l}\text { 14- I always provide comments about the learning } \\
\text { process. }\end{array}$} \\
\hline \multicolumn{5}{|l|}{ 15- I accept the students' point of views. } \\
\hline \multicolumn{5}{|l|}{$\begin{array}{l}\text { 16-My feedback to the student's teaching practice } \\
\text { is efficient and clear. }\end{array}$} \\
\hline $\begin{array}{l}\text { 17- I always hold meetings at the university to } \\
\text { discuss what happens at the school. }\end{array}$ & & & & \\
\hline
\end{tabular}


c. In relation to planning and implementing lessons:

\begin{tabular}{|l|l|l|l|l||}
\hline & & & & \\
\hline \hline $\begin{array}{l}\text { 18- The student teacher always starts with prior } \\
\text { accurate lessons planning. }\end{array}$ & & & & \\
\hline $\begin{array}{l}\text { 19- The student teacher is able to form the behavioral } \\
\text { objectives perfectly }\end{array}$ & & & & \\
\hline $\begin{array}{l}\text { 20- The student teacher is able to manage the } \\
\text { class. }\end{array}$ & & & & \\
\hline $\begin{array}{l}\text { 21-The student teacher is able to manage } \\
\text { discussions and asking questions. }\end{array}$ & & & \\
\hline $\begin{array}{l}\text { 22-It is easy for the student teacher to deal with } \\
\text { students' different levels and backgrounds. }\end{array}$ & & & \\
\hline
\end{tabular}




\section{AN EVALUATIVE STUDY OF THE ENGLISH PRACTICUM PROGRAM}

d. In relation to the cooperating teacher :

\begin{tabular}{|l|l|l|l|l|}
\hline & & & & \\
\hline \hline $\begin{array}{l}\text { 23- The cooperating teacher needs training on how } \\
\text { to deal with the training program. }\end{array}$ & & & & \\
\hline $\begin{array}{l}\text { 24-The cooperating teacher wants the student } \\
\text { teacher to teach subjects she taught to her students } \\
\text { before. }\end{array}$ & & & & \\
\hline $\begin{array}{l}\text { 25- The cooperating teacher helps the student } \\
\text { teacher to attend the classes of her peers } \\
\text { regularly. }\end{array}$ & & & & \\
\hline $\begin{array}{l}\text { 26- The cooperating teacher provides enough } \\
\text { support to the student teachers. }\end{array}$ & & & \\
\hline
\end{tabular}

\section{e. In relation to the cooperating school :}

\begin{tabular}{|l|l|l|l|l|}
\hline & & & & \\
\hline \hline $\begin{array}{l}\text { 27-The cooperating school does not provide } \\
\text { necessary teaching aids }\end{array}$ & & & & \\
\hline $\begin{array}{l}\text { 28- The cooperating school does not provide } \\
\text { a meeting room for me and the student teachers. }\end{array}$ & & & \\
\hline $\begin{array}{l}\text { 29- Students at school do not look at the student } \\
\text { teacher as a teacher and follow her instructions }\end{array}$ & & & & \\
\hline $\begin{array}{l}\text { 30-classes are very crowded so the student } \\
\text { teacher is not able to implement what she has } \\
\text { learnt at the university. }\end{array}$ & & & & \\
\hline $\begin{array}{l}\text { 31-school books and teacher's handbook are not } \\
\text { always available. }\end{array}$ & & & & \\
\hline
\end{tabular}

